\title{
Assessing Wetlands with Habitat Providers: A Landscape Approach for Handling Degraded Areas for Coal Mining
}

\author{
Viana IR ${ }^{1,2 *}$ and Zocche $\mathrm{JJ}^{2,3}$ \\ ${ }^{1}$ Landscape Ecology Laboratory, Rio de Janeiro State University, Brazil \\ ${ }^{2}$ Laboratory of Landscape and Vertebrate Ecology, Extremadura South University \\ Catarinense, Brazil \\ ${ }^{3}$ Graduate Program in Environmental Sciences, Extremadura South University \\ Catarinense, Brazil
}

*Corresponding author: Ivan Réus Viana, Landscape Ecology Laboratory, Rio de Janeiro State University, Rio de Janeiro, RJ, Brazil, Tel: +5548996260398; E-mail: reusviana@gmail.com

\section{Abstract}

Land-use changes can decrease the number of individuals and species in certain areas, and diminish or impede movements in landscapes. Here we evaluated the potential of constructed wetlands as habitat providers for birds in coal mining areas in a landscape at the Brazilian Atlantic Forest. We compared bird diversity in different kinds and proportions of natural and anthropogenic habitats. Analyses were performed for species with different ecological requirements to evaluate wetland with habitat providers. This allowed evaluating the sensibility of species from the species-specific level to the multispecific level (trophic guilds). About 70\% of the bird species used two or more habitats to perform their vital functions, reflecting a key-role of landscape composition in explaining the similar traits between bird species and landscape connectivity. The approach presented in this study can be applied in degraded landscapes by coal mining: it will facilitate decisions on management to connectivity and conservation.

Keywords: Bird diversity: Connective elements: Restoration: Landscape composition: Multi-species

\section{Introduction}

Habitat loss and fragmentation are regarded as the major drivers of global biodiversity loss [1]. Changes in the distribution and spatial configuration of patches occur as a result of these processes [2]. Habitat loss decreases the number of individuals and species that can live in a certain area, and can diminish or impede movements among isolated patches [3]. Matrix quality and composition also influence the occurrence, establishment, survival and dispersal of organisms [4]. The dispersal potential of a species can be limited by the creation of barriers created during the process of habitat loss [5].

Habitat loss has been shown to reduce trophic chain length, to alter species interactions, and to reduce the number of specialist species [6-8]. Habitat loss also negatively affects breeding success, dispersal success $[9,10]$, and aspects of animal behavior that affect foraging success rate [11]. Unlike fragmentation, connectivity is considered a vital element to landscape, contributing to survival and to population dynamics [12]. Connectivity is 


\section{Journal of Ecology \& Natural Resources}

'the degree to which the landscape facilitates or impedes movement along resource patches' and is both species and landscape-specific $[13,14]$. Thus, strategies that tend to increase landscape connectivity, as the implementation of connectors' elements, may contribute to maintain biodiversity in impacted sites [15].

Birds vary greatly in their use of fragmented landscapes, from species restricted to a single unit of the landscape to species that occupy an entire region [16]. Recent studies have shown declines in bird diversity due to anthropogenic disturbance, as habitat loss $[17,18]$. Thus, landscape composition becomes an important environmental feature for the diversity of birds, since they are distributed heterogeneous way among the landscape units $[19,20]$.

To understand the potential of constructed wetlands as connectivity elements for birds in a coal mining area, here we tested:

I. If the variation in the richness of bird species is related to the proportion of each habitat in the landscape.

II. How bird community, functional groups and individual species are affected by landscape composition.

III. If the landscape composition and/or environmental factors (year seasons) are important explanatory variables for the diversity of species in the landscape.

\section{Material and Methods}

\section{Study Area}

Birds were studied in the municipality of Forquilhinha, southern portion of Santa Catarina State, southern Brazil (28ㄴㄱ'19" S, 4926'32" W, Figure 1). The study area is characterized by ombrophilous forests, whereby dense forest patches are intermingled with a matrix composed mainly of open areas (such as cropland, fallow fields, pastures and native vegetation), rural installations and coal mining activities [21]. The climate, according to the Alvares, et al. [22] classification, is humid subtropical (Cfa), i.e. constantly moist subtropical climate, with no dry season, hot summers, and average temperature of the warmest month exceeding $22{ }^{\circ} \mathrm{C}$. Mean annual precipitation is about $1220-1660 \mathrm{~mm}$, with a total of 102-150 rainy days per year, evenly distributed throughout the year [23].

The exploration of Catarinense coal basin began around 1940 and since then has caused physical, chemical and biological changes in local ecosystems [24]. The water, soil and biota resources were directly affected over an area that varies from 2000 to 6000 ha [25]. Nowadays, the residue obtained after crude coal improvement is discarded into controlled piles of pyritic residues. But in the past it was carelessly disposed anywhere [24]. The contact of the residues with air and water generates acid mine drainage (AMD), which can contaminate the environment and cause additional impacts due to physical changes in terrestrial and aquatic ecosystems. An alternative to complement the physicochemical treatments conventional in areas with AMD is the phytoremediation, a kind of bioremediation [26]. Constructed wetlands for phytoremediation can be described as a passive system for the final polishing of the effluent capable of removing metals still present in the AMD through filtering by plants [27]. This wetland forces the passage of AMD for an area of approximately 2.1 hectares, with a water depth of 0.30 to $0.50 \mathrm{~m}$. The vegetation that spontaneously developed consists of aquatic macrophytes, mainly Poaceae, Cyperaceae, Juncaceae and Typhaceae families.

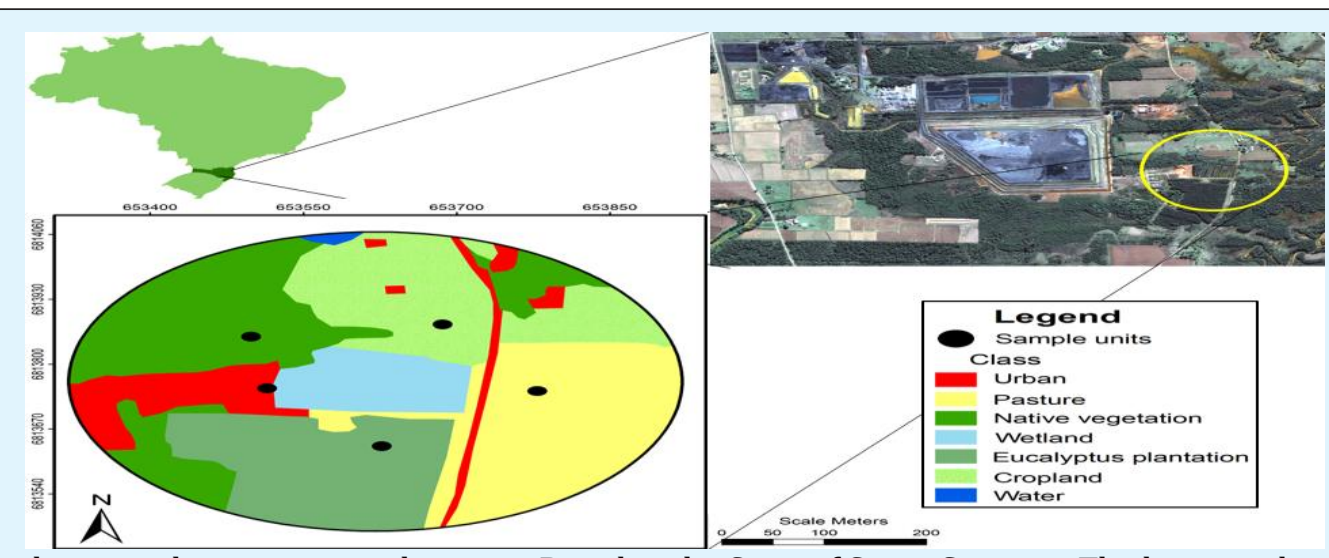

Figure 1: The study region location in southeastern Brazil in the State of Santa Catarina. The large-scale map illustrates in detail the landscape and the locations of the sample units (black dots). 


\section{Journal of Ecology \& Natural Resources}

\section{Data Collection}

The composition of the landscape surrounding the wetland was obtained from land cover maps, generated by photo-interpretation of orthophotos with $30 \mathrm{~m}$ resolution from 2012, projected in UTM SAD 1969 (Secretaria de Desenvolvimento Regional de Santa Catarina, SDS/SC - 2013). All map processing procedures were performed in ArcGIS 9.3. The landscape composition was determined within a circular buffer area with a radius of $300 \mathrm{~m}$ surrounding the central point of the constructed wetland. We classified the different land-use types into seven classes (in hectares): wetland (2.1): Native vegetation (9.1): Pasture (4.4): Cropland (5.0) and Eucalyptus plantation (5.0), in addition to urban (2.7) and water (0.1), not considered in the analysis (Figure 1).

We conducted a bird survey using the Mackinnon lists technique [28] with 10 species lists as suggested by Ribon $R$ [29]. The counts were recorded one hour at each point and repeated two times during all year seasons (spring, summer, autumn and winter) between 2011 and 2012, in a total of eight visits to each habitat. Sampling began at approximately sunrise $(\sim 6: 00 \mathrm{~h})$ and lasted about $5 \mathrm{~h}$. Sampling points were arranged $50 \mathrm{~m}$ away from the wetland edges (Figure 1). The survey was undertaken by only one observer (the first author), avoiding potential biases related to different bird identification capacities. Whenever there was any doubt about bird song, it was recorded for later identification. To avoid sampling bias in each visit the first sample point was randomly selected and a sequential survey was undertaken in the other points. Based on this survey, we calculated for each species, the lists frequency index (LFI), where the numbers of visual or audio contacts with individuals of one species are divided by the total number of sampled lists [29].

Based on Sick, species were grouped in the following trophic guilds: CA - Carnivorous: FR - Frugivorous: GR Granivorous: IN - Insectivorous: NE - Nectivorous: ON Omnivorous: SC - Scavengers and PI - Piscivorous. As well as the kind of activity (foraging, resting or reproduction) [30].

\section{Data Analysis}

To evaluate if the sampling effort was sufficient to obtain a good estimate of species richness, we constructed species accumulation curves as a function of effort, measured in number of lists. The adequacy of records effort was evaluated by nonparametric estimation Bootstrap, considering the richness based on the incidence of species [31]. Three metrics were calculated to characterize bird diversity within each habitat: (i) species richness (R): (ii) Shannon diversity $\left[H^{\prime}=-\Sigma p i\right.$ ln $p i$, where $p i$ is the relative frequency of species $I]$ : and (iii) abundance of individuals $(\mathrm{N})$.

To determine the degree of association among the variables, we submitted the recorded species number in each habitat related to year seasons to Principal component analysis (PCA). PCA was chosen to minimize the effects of multicollinearity and to reveal patterns between habitats using standardized data (zero mean and unit standard deviation) [32]. All analyses were performed in R 3.0.1 [33].

\section{Results}

We recorded 1,530 contacts with birds (153 lists) from 95 species, classified into 16 orders and 35 families (Table S1). The families best represented were Tyrannidae (13.7\%), Thraupidae (10.5\%), Furnariidae (6.3\%), and Ardeidae, Columbidae, and Icteridae (5.3\%), corresponding to $46.4 \%$ of records. The other families were represented between one and four species, corresponding from 1.1 to $4.2 \%$ of all species recorded. The species accumulation curve indicated that $95.5 \%$ of the total number of species expected for the area were recorded (Figure S1). Few species (8\% of the total) were relatively abundant (i.e. present in $>50$ lists). Occasional and rare birds (occurring < 4 lists) were the most frequent with 32 species (34\%). Finally, common and frequent species represented an intermediate richness (32\% and $26 \%$, respectively: Table S1).

Regarding trophic categories, insectivorous represented $39 \%$ of the avifauna in each habitat, followed by omnivorous $(33 \%)$, granivorous $(12.3 \%)$ and others $(16 \%)$. The exception was the pastures, which had more omnivorous than insectivorous species, reflecting the existing interrelationships between the birds and the habitats.

Birds occupied the habitats in the following order: Native vegetation (45.4\%), Pasture (19.5\%), Cropland $(14.5 \%)$, wetland $(12.3 \%)$ and Eucalyptus plantation (8.3\%). About 28 species were exclusively of one habitat: Native vegetation (18), pasture and eucalyptus plantation (4), cropland and wetland (1) (Table 1). Birds that occupied two habitats totaled 14 species, 20 species in three habitats, 16 species in four habitats and 13 species in five habitats (Table S1). Among 95 recorded species, 40 
species (42\%) used the wetland for some kind of activity (foraging, resting or reproduction).

\begin{tabular}{|c|c|c|c|c|c|}
\hline Habitat & (\%) Ha & (\%) O & OE & EE & H' $^{\prime}$ \\
\hline Cropland & 17.5 & 14.5 & 45 & 1 & 3.40 \\
\hline Native vegetation & 32.0 & 45.4 & 74 & 18 & 3.92 \\
\hline Eucalyptus plantation & 17.6 & 8.3 & 31 & 4 & 3.32 \\
\hline Pasture & 15.6 & 19.5 & 45 & 4 & 3.28 \\
\hline Wetland & 7.3 & 12.3 & 39 & 1 & 3.25 \\
\hline Urban & 9.6 & - & - & - & - \\
\hline Water & 0.4 & - & - & - & - \\
\hline
\end{tabular}

Table 1: Relationships between habitat availability and use by birds in the studied landscape in southern Brazil. (\%) Ha- Percentage of available habitat: (\%) 0Occupation percentage: OE-Observed species: EEExclusive species and $\mathrm{H}^{\prime}$-Shannon Diversity Index.

Principal component analysis (PCA) revealed the existence of proximity between the species richness in the habitats in relation to the seasons. There were associations between the wetland and eucalyptus plantation in the winter when the generalist species seek food in the wetland (e.g. Pitangus sulphuratus, Milvago chimachima). Cropland had species in a constant both in spring and autumn, periods where crop harvests are made. Native vegetation and pasture had close relationship with only one season (summer and spring, respectively), where we found species using these habitats only for reproduction (e.g. Thamnophilus caerulescens and Anthus lutescens, respectively: Figure 2).

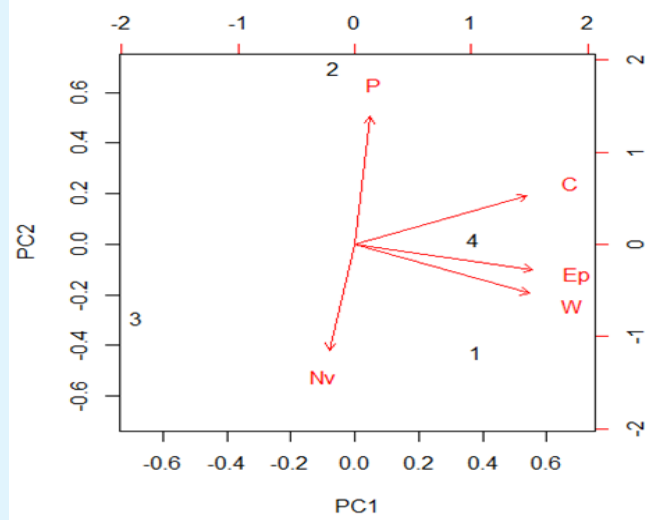

Figure 2: Distribution of birds in the five habitats, W Wetland: $\mathrm{Nv}$ - Native vegetation: Ep - Eucalyptus plantation: P - Pasture and C - Cropland. The number associated to the letters represents the year seasons where: 1 - Winter: 2 - Spring: 3 - Summer and 4 Autumn.

\section{Discussion}

Our results suggest that for land use management, the landscape composition need to be accounted for to maintain suitable conditions for biodiversity [14]. Landscapes fragmented by coal mining activities may be important habitat providers by providing an adapted spatial configuration for birds. Overall, heterogeneous landscapes appear to be useful in facilitate, in some places, movement between two or three habitats areas favorable for different groups of species [34]. The values of species abundance in each habitat can be directly translated into connectivity (habitat use) levels because the landscape scale accounts for spatial characteristics that explain the distribution of species. This approach allows comparing the different habitat use by species with different ecological requirements as well as groups of species, and it allows for the transition from the speciesspecific level to the multispecific level.

Availability of habitat showed a relation of dependence on specific environments which distribute the birds in the landscape according to their needs [30]. We did not find species dependent especially on cropland. However, the species that occupy the pasture tend to be associated with cropland areas due to their mobility and their tolerance to habitat disturbance [35]. This result can be explained by the fact that many of these species are generalists and present a higher dispersal capacity, as, for example: Furnarius rufus, Sicalis flaveola, Pitangus sulphuratus and Zonotrichia capensis [36]. Bird community composition undergoes changes when changes occur in vegetation, food supply and mainly climate $[19,14]$. Habitats with small proportions in the landscape were used by a large portion of the bird community, due to the conditions available for the species. According to the proportion of habitat available, we had a high number of species $(78 \%)$ in native vegetation by their larger proportion in the landscape (32\%). However, wetland was also used by a relatively high number of species $(12.3 \%)$, although it occupied only a small proportion of habitat in the landscape (7.3\%).

Landscape composition may influence the partitioning of species in and around wetlands according to food availability/abundance in each habitat and the trophic niches of the bird species sharing that habitat [37]. Although previous studies grouped species based mainly on trophic guilds [38], we found that additional characteristics of many species can be useful for distinguishing whether their responses are influenced by landscape composition. Restrictions on use the five 


\section{Journal of Ecology \& Natural Resources}

habitats highlight to unique characteristics by species, due to their wide ecological and trophic niches, and because of their ability to adapt quickly to changes in habitat [39]. For example, in our study area, Schiffornis virescens, Habia rubica, Platyrinchus mystaceus where restrict to native vegetation: Anthus lutescens was restricted to pasture: and Amazonetta brasiliensis was restricted to wetland. In addition, $70 \%$ of the remaining species used two or more habitats to perform their vital functions (e.g. foraging, resting, mating, reproduction). Landscape composition effects may play a key-role in explaining the similar features between bird species [40].

The ability of species to move among different habitats is determined by physiological and morphological constraints of each species, and also by sensorial ability to perceive the landscape [41]. According to Regalado and Silva the highest frequency of insectivorous species is due to the fact this group contains generalist species that live in open areas, and species that only occupy the interior forests (e.g. Tyrannus melancholicus, Tachyphonus coronatus, respectively) [42]. On the other hand, the group of omnivorous species contains species that occupy multiple trophic levels, which quickly respond to existing disturbances on the landscape [43]. Environmental changes can lead to an increase of omnivorous birds (generalists) and less specialized insectivorous, with the decrease of frugivorous and more specialized insectivorous (specialists) [44].

Some studies suggest that different types of matrix have different degrees of permeability, offering different resistances to displacement or occurrence of different species $[10,3]$. For example, species that needs vegetation to move between habitats (Myiophobus fasciatus and Satrapa icterophrys), species that utilize the pasture and cropland owing to proximity those habitats in landscape (Colaptes campestris and Vanellus chilensis), restricted species to one habitat only (Myiothlypis leucoblephara and Schiffornis virescens) and species with high ecological plasticity that occupy all habitats (Furnarius rufus, Zonotrichia capensis, Guira guira and Pitangus sulphuratus: [30]. Seasonality also may reflect the food shortage in some habitats and motivates the search for others. The lower diversity of birds in the eucalyptus plantation and wetland in winter may reflection a low food supply in these habitats. Winter is a critical period for most birds, given that winter food availability may affect the occurrence and abundance of many species, thus conditioning their chances of survival until the breeding period [45].
The approach presented in this study holds promise as a tool to potentialize connectivity paths and identify sensitive habitat areas for species that live in different habitats or have different ecological requirements. Thus, to conserve biodiversity in landscapes disturbed by coal mining, a combined strategy of protection and restoration of wetlands should be considered, in order to include opportunities for sustainable coal mining that preserve landscape composition. This study provides useful information to understand which groups of species are able to use different types of habitat surrounding coal mining areas. It also shows how valuable a single waterbody can be for a wide range of species with different ecological needs. Finally, our results supported the notion of the importance of wetlands conservation for the maintenance of bird communities and ecological processes that ensure the functioning of small forest patches in surroundings of wetlands.

\section{References}

1. Ewers RM, Didham RK (2006) Confounding factors in the detection of species responses to habitat fragmentation. Biol Rev 81(1): 117-142.

2. Fahrig L (2003) Effects of habitat fragmentation on biodiversity. Annu Rev Ecol Syst 34: 487-515.

3. Ricketts TH (2001) The matrix matters: Effective isolation in fragmented landscapes. Am Nat 158(1): 87-99.

4. Prevedello JA, Vieira MV (2010) Does the type of matrix matter? A quantitative review of the evidence. Biodiv Conserv 19(5): 1205-1223.

5. Mazerolle MJ, Villard MA (1999) Patch characteristics and landscape context as predictors of species presence and abundance: a review. Ecoscience 6(1): 117-124.

6. Komonen A, Penttila R, Lindgren M, Hanski I (2000) Forest fragmentation truncates a food chain based on an old-growth forest bracket fungus. Oikos 90(1): 119-126.

7. Taylor PD, Merriam G (1996) Habitat fragmentation and parasitism of a forest damselfly. Landsc Ecol 11(3): 181-189.

8. Gibbs JP (2001) Demography versus habitat fragmentation as determinants of genetic variation in wild populations. Biol Conserv 100(1): 15-20. 


\section{Journal of Ecology \& Natural Resources}

9. Kurki S, Nikula A, Helle P, Lindén H (2000) Landscape fragmentation and forest composition effects on grouse breeding success in boreal forest. Ecology 81(7): 1985-1997.

10. Pither J, Taylor PD (1998) An experimental assessment of landscape connectivity. Oikos 83(1): 166-174.

11. Mahan CG, Yahner RH (1999) Effects of forest fragmentation on behaviour patterns in the eastern chipmunk (Tamias striatus). Can J Zool 77(12): 19911997.

12. Fahrig L, Paloheimo J (1988) Determinants of local population size in patchy habitats. Theor Popul Biol 34: 194-213.

13. Taylor PD, Fahrig L, Henein K, Merriam G (1993) Connectivity is a vital element of landscape structure. Oikos 68(3): 571-573.

14. Tischendorf L, Fahrig L (2000) How should we measure landscape connectivity? Landsc Ecol 15(7): 633-641.

15. Laurance SGW (2004) Landscape connectivity and biological corridors. In: Schroth G, Fonseca G (Eds.), Agroforestry and Biodversity Conservation in Tropical Landscapes. Island Press, USA, pp: 50-63.

16. Marine MA, Garcia FI (2005) Bird conservation in Brazil. Conserv Biol 19(3): 665-671.

17. Banks Leite C, Ewers RW, Metzger JP (2010) Edge effects as the principal cause of area effects on birds in fragmented secondary forest. Oikos 119(6): 918926.

18. Ferraz G, Nichols JD, Hines JE, Stouffer PC, Bierregaard RO, et al. (2007) A Large-Scale Deforestation Experiment: Effects of Patch Area and Isolation on Amazon Birds. Science 315(5809): 238241.

19. Aleixo A (1999) Effects of a selective logging on a bird community in the Brazilian Atlantic Forest. Condor 101: 537-548.

20. Shanahan DF, Possingham HP (2009) Predicting avian patch occupancy in a fragmented landscape: do we know more than we think? J Appl Ecol 46(5): 10261035.
21. Leite PF, Klein RM (1990) Geografia do Brasil: Região Sul Vegetação. In: IBGE (Ed.), Geografia do Brasil. Rio de Janeiro, pp: 113-150.

22. Alvares CA, Stape JL, Sentelhas PC, Gonçalves, Sparovek G, et al. (2014) Köppen's climate classification map for Brazil. Meteorol Z 22(6): 711728.

23. (2001) EPAGRI - Empresa de Pesquisa Agropecuária e Extensão Rural de Santa Catarina S.A.. Centro de Informações de Recursos Ambientais e de Hidrometeorologia de Santa Catarina.

24. CETEM-Centro de Tecnologia Mineral (2001) Projeto conceitual para recuperação ambiental da Bacia Carbonífera Sul Catarinense. SIECESC, Criciúma: 78.

25. Zocche JJ, Silva LA, Damiani AP, Mendonça RÁ, Peres PB, et al. (2014) Heavy metal content and oxidative damage in Hypsiboas faber: the impact of coal mining pollutants on amphibians. Arch Environ Com Tox 66(1): 69-77.

26. Coutinho HD, Barbosa AR (2007) Fitorremediação: considerações gerais e características de utilização. Oeiras 15(1): 103-117.

27. Cunningham S, Berti WR (1993) The remediation of contaminated soils with green plants: an overview. In vitro cell dev-pl 29(4): 207-212.

28. Mackinnon J (1991) Field Guide to the Birds of Java and Bali. Gadjah Mada University Press, Java, pp: 692.

29. Ribon R (2010) Amostragem de aves pelo método das listas de Mackinnon. In: Matter SV, Straube F, Accordi I (Eds.), Ornitologia e Conservação: ciência aplicada, técncias de pesquisa e levantamento. Rio de Janeiro: Technical Books, pp: 1-16.

30. Sick H (2001) Ornitologia brasileira: uma introdução. Brasília: Nova Fronteira, pp: 914.

31. Colwell RK, Coddington J (1994) Estimating terrestrial biodiversity through extrapolation. Philos. T Roy Soc B 345(1311): 101-118.

32. Legendre P, Legendre L (1998) Numerical ecology. Amsterdam: Elsevier.

33. R Core Team (2013) R: A language and environment for statistical computing. R Foundation for Statistical Computing, Vienna, Austria. 


\section{Journal of Ecology \& Natural Resources}

34. Mimet A, Houet T, Julliard R, Simon L (2013) Assessing functional connectivity: a landscape approach for handling multiple ecological requirements. Methods Ecol Evol 4(5): 453-463.

35. Lens L, Van Dongen S, Norris K, Githiru M, Matthysen E (2002) Avian persistence in fragmented rain forest. Science 298(5596): 1236-1238.

36. Uezu A, Beyer DD, Metzger JP (2008) Can agroforest woodlots work as stepping stones for birds in the Atlantic Forest region? Biodivers Conserv 17(8): 1907-1922.

37. Bensizerra D, Chenchounib H, Si-Bachirc A Houhamdid M (2013) Ecological status interactions for assessing bird diversity in relation to a heterogeneous landscape structure. Avian Biol Res 6(1): 67-77.

38. Ribon R, Simon JE, De Mattos GT (2003) Bird extinctions in Atlantic Forest Fragments of Viçosa Region, Southeastern Brazil. Conserv Biol 17(6): 1827-1839.

39. Barnard P, Thuiller W (2008) Introduction. Global change and biodiversity: future challenges. Biol Lett 4(5): 553-555.
40. Awade M, Metzger JP (2008) Using gap-crossing capacity evaluate functional connectivity of two Atlantic rainforest birds and their response to fragmentation. Austral Ecol 33(7): 863-871.

41. Forero-Medina G, Vieira MV (2007) Conectividade funcional e a importância da interação organismopaisagem. Oecol Bras 11(4): 493-502.

42. Regalado LB, Silva C (1997) Utilização de aves como bioindicadoras de degradação ambiental. Rev Bras Ecol 1: 81-83.

43. Fagan WF (1997) Omnivory as a stabilizing feature of natural communities. Am Nat 150(5): 554-567.

44. Donatelli RJ, Da-Costa TV, Ferreira CD (2004) Dinâmica da avifauna em fragmento de mata na Fazenda Rio Claro, Lençóis Paulista, São Paulo, Brasil. Ver Bras Zool 21(1): 97-114.

45. Telleria JL, Virgós E, Carbonell R, Pérez-Tris J, Santos $T$ (2001) Behavioural responses to changing landscapes: Flock structure and anti-predator strategies of tits wintering in fragmented forests. Oikos 95(2): 253-264. 